Original scientific paper - Izvorni znanstveni rad

UDK: $637.35^{\prime} 639$

\title{
Production of hard goat cheese and goat whey from organic goat's milk
}

\author{
doi: $10.15567 /$ mljekarstvo.2017.0302
Anka Popović-Vranješ ${ }^{*}$, Ivan Pihler ${ }^{1}$, Snežana Paskaš ${ }^{1}$, Saša Krstović ${ }^{1}$ Željka Jurakić ${ }^{1}$, Katarina Strugar ${ }^{2}$ \\ ${ }^{1}$ University of Novi Sad, Faculty of Agriculture, Department of Animal Science, \\ Trg DositejaObradovića 8, Novi Sad, Serbia \\ ${ }^{2}$ Provincial Secretariat of Agriculture, Water Resources and Forestry, \\ Bulevar Mihajla Pupina 16, Novi Sad, Serbia \\ Received - Prispjelo: 06.03.2017. \\ Accepted - Prihvaćeno: 25.05.2017.
}

\begin{abstract}
Technology of hard goat cheese and whey production from organic goat's milk is very complex and must be harmonized with the methods and guidelines of organic production. The organic goat cheeses are declared as products of higher quality, with greater or added value, and to achieve this, all technological parameters of production must be controlled and adapted to the desired type of cheese. In this study chemical analyses of the composition of organic and conventional goat's milk, cheese and whey were performed. Cheese fatty acids profile was determined by gas chromatograph (GC) with FID detector, while for detection of amino acids was used HPLC method with fluorescence detection. Data obtained in the study were analyzed using Statistica 9.0 software package and significant differences were determined using t-test. Based on the results, organic milk was statistically significantly higher in all components, except in ash and sodium $(\mathrm{p}<0.05, \mathrm{p}<0.01)$. Contrary, cheeses (aged 4 days) did not show significant differences ( $<<0.05, p<0.01$ ), except for dry matter and lactose. During ripening of organic cheese the contents of threonine, tyrosine, valine and isoleucine decreased, whereas methionine, phenylalanine and lysine, showed a tendency to increase. Saturated fatty acids were mainly represented with myristic, palmitic and stearic acids while oleic acid was dominant as unsaturated FA. Organic whey samples contained significantly more protein $(1.43 \%$ versus $0.52 \%, \mathrm{p}<0.05, \mathrm{p}<0.01)$. The application of organic standards of manufacture and control of all technological parameters in the production of organic hard goat cheese and whey resulted in obtaining a high-quality products.
\end{abstract}

Key words: technology, organic hard goat cheese, whey

\section{Introduction}

Today, changes in the human diet include not only organic fruits and vegetables but it is also an increasing demand for organic dairy products. The market of organic dairy products represents $11 \%$ of the total world market of organic food with annual increase of about $6 \%$ (OMSCo, 2015). The largest part of the produced goat milk is consumed as cheese and yogurt (Haenlein, 2004), whereby goat cheeses with its uniqueness in taste and texture are especially prominent (Morand-Fehr et al., 2004).
Organic food production is determined by standards and rules that define the raw material, permitted additives, technology, packaging, storage and transport of products. The organic goat cheese is made from organic goat milk which should represent at least $95 \%$ of the total components. In cheese production are also used not organic ingredients, and their share should not exceed $5 \%$. Preparations of genetically obtained/modified microorganisms and enzymes originating from genetic engineering cannot be used. The use of chemical preservatives should be reduced to a minimum. For milk coagulation, 
the usage of $\mathrm{CaCl}_{2}$ is permitted, while lactic, citric and hydrochloric acid can be used for regulating the $\mathrm{pH}$ of the brine. Moreover, in use are certain spices, fats, vegetable oils and natural flavors that are not obtained by organic production methods. Regarding non-agricultural ingredients, vegetable carbon (Ashy goat cheese) annatto, bixin and norbixin are allowed (EC, 2008; EEC, 1993). This technology is new and recently considered in the dairy industry.

The quality of organic goat milk comes from organic production management and from animal nutrition in organic farming. The organic milk, which contains more dry matter and nutrients represents a quality raw material to obtain products of exceptional nutritional and functional properties. The quality and technological properties of milk are best assessed by its chemical composition and physical properties, particularly the total dry matter content, fat and protein (Dozet et al., 1979). Standard chemical composition of organic and conventional goat milk has been the subject of numerous studies and thereby obtained highly opposing results. Malissiove et al. (2015) found no significant differences. On the other hand, Tudisco et al. (2010) and Bovera et al. (2007) recorded higher fat content in organic milk, while Pajor et al. (2014) apart from the fat, found higher protein content and nonfat dry matter in organic goat milk.

The organic hard cheeses like artisan goat and cheese with geographical origin are often produced from raw milk in the traditional way. However, hard cheeses are now produced from pasteurized milk by adding thermophilic starter culture and with curd drying at temperatures of $39-42{ }^{\circ} \mathrm{C}$, to form a solid consistency of cheese (Popović-Vranješ, 2015). With a variety of advanced technologies for obtaining goat cheese in different parts of the world and the significant variation in the composition of goat milk, goat cheese yields are also very variable (Park and Haenlein, 2006). A number of basic ingredients that pass from milk into cheese and whey expressed their distribution, which is particularly important in the production of traditional cheeses where special attention is paid to the exploitation of fat and protein. It affects the yield of the cheese, but also indicates the technology of cheese (Savić et al., 2015). Market goat cheese represents the primary source of income for producers of goat's milk and for these reasons efficient production of cheese for them is always more challenging compared to producers of cow's milk (Wolf, 2014).
Consumption of components used in the cheese production can be monitored through whey quality whereby different varieties of cheese have different whey quality. The differences are in specific acidity and the content of nutrients. The practice of treating whey as waste and using its nutritional value only as a livestock feed is abandoned long time ago. Whey and its preparations are now referred to as the forgotten treasures and for its unique properties; it is rediscovered and increasingly used in food industry (Krolczyk et al., 2016). Today, in the EU, $25 \%$ of the total produced whey is used in human food, while in the USA it amounts to more than $50 \%$ (EDA, 2016). Goat whey contains more important nutrients, possesses exceptional nutritional and qualitative characteristics, and is an essential part of every healthy meal. Commercial production of organic cheese, whey and whey protein concentrate is still at the beginning of its development and presents the possibility of obtaining a number of functional products.

The purpose of this research is to describe the production of organic hard goat cheese and whey. It also provides an overview of chemical parameters with special emphasis on the impact of organic farming to the production, quality of organic milk and derived products: cheese and whey.

\section{Materials and methods}

\section{Milk}

Samples of organic $(n=10)$ and conventional goat milk $(n=10)$ were taken directly from the goat breeders. Organic milk samples were taken from certified organic goat breeder. Goats were in the same stage of lactation and belong to the same breed (Alpine). The samples were collected during the last 3 months of lactation, arranged in the same time intervals. Analyses of milk, cheese and whey were performed in the laboratories of the Department of Animal Science, Faculty of Agriculture, Novi Sad (Republic of Serbia). Standard analysis of the chemical composition of organic and conventional goat milk was done with the MilkoScan FT + analyzer using the FTIR technique. MilkoScanTM + FT techniques were in accordance with ISO 9622 / IDF 141: 2013 and AOAC official methods 972.16. For the determination of somatic cells in raw milk FossomaticFT FC (ISO 13366-2) was used, and for a total number of bacteria BactoScanTM FC + (ISO 16297). 


\section{Cheese and whey}

Goat cheese and whey from organic $(n=10)$ and conventional goat milk $(\mathrm{n}=10)$ are produced in a dairy plant "Dana”, Vrbas (Republic of Serbia). Basic technological parameters of hard goat cheeses that are related to the type of milk, heat treatment of milk, coagulation, cutting the curd, processing and parameters curd, salting and ripening cheeses are shown in Table 1 .

After the completion of the coagulation, cooling and brining, samples were taken and analyzed. The chemical parameters as the parameter of the cheese quality were determined. The composition of cheese and whey were determined by standard methods: total dry matter with a standard method of measuring weight loss after drying (AOAC 926.08-1927), for protein Kjeldahl - Van Slyke method for determination of the total $\mathrm{N}$ was used (AOAC 2001.14), milk fat content was determined according to Gerber method (AOAC 933.05), lactose by Bertrand method (AOAC, 930.32), the ash by dry ashing at $550{ }^{\circ} \mathrm{C}$ (AOAC 935.42). The $\mathrm{pH}$ was measured by a $\mathrm{pH}$ meter (WTW, type ino Lab $\mathrm{pH}$ 720) (AOAC 981.12), and titratable acidity by Soxlet-Henkel (Sabadoš, 1996). The presence of heavy metals and trace elements were done by atomic absorption spectrophotometry (AAS) using the atomic absorption spectrometer (Perkin-Elmer, type PinAAcle 900T) (AOAC 999.11). Phosphorus was determined by spectrophotometer (PG Instruments, type T80+) (AOAC 995.11), while for $\mathrm{Ca}, \mathrm{Na}$ and $\mathrm{K}$ flame photometry (Sherwood, type M410) was used (Kirk and Sawyer, 1991). Samples of organic goat cheese (ripening 60 and

Table. 1. Technological parameters of hard goat cheese

\begin{tabular}{|c|c|}
\hline Parameters & \\
\hline Cheese milk & Goat milk 7.2-7.4 ${ }^{\circ} \mathrm{SH}$ \\
\hline Pasteurization $\left({ }^{\circ} \mathrm{C} / \mathrm{sec}.\right)$ & $65^{\circ} \mathrm{C} / 5 \min$ \\
\hline Cooling of milk & $36^{\circ} \mathrm{C}$ \\
\hline Starter cultures (\%) & Thermophilic and mesophilic (TCC20 and CHN11) \\
\hline $\mathrm{CaCl}_{2}$ & $0.02 \%$ \\
\hline Organic maturation of milk & $20 \mathrm{~min}$ \\
\hline Renneting temp. $\left({ }^{\circ} \mathrm{C}\right)$ & Temperature of coagulation $32-34{ }^{\circ} \mathrm{C}$ \\
\hline Rennet & Rennet $3.5-4.5 \mathrm{~g} \mathrm{x} 100 \mathrm{~L}$ \\
\hline Renneting time (min) & $35-40 \mathrm{~min}$ \\
\hline I curd cutting & The size of a hazelnut, stirring, $5 \mathrm{~min}$ \\
\hline Reheating & Slow reheating $39-40{ }^{\circ} \mathrm{C}, 10 \mathrm{~min}$ \\
\hline II curd cutting & The size of grains of maize \\
\hline Stirring and drying curd grains & $42-43^{\circ} \mathrm{C}$, drying curd grains $35-45 \mathrm{~min}$ \\
\hline Squeezing $1 / 2$ of whey & Standstill cheese curd and draining of $1 / 2$ whey, $5-10 \mathrm{~min}$ \\
\hline Cheese pressing and acidification & $\begin{array}{l}\text { The acidity of whey at the cutting time } 3.8-4.2^{\circ} \mathrm{SH} \\
\text { Final acidity of the whey } 4.4-4.8^{\circ} \mathrm{SH} \\
\text { Molding of the cheese mass and pressing: } \\
30 \mathrm{~min} / 2 \mathrm{bar} \\
60 \mathrm{~min} / 3 \mathrm{bar}\end{array}$ \\
\hline Cooling & Cooling 12 hours $/ 10-12^{\circ} \mathrm{C}$ \\
\hline Salting into brine & Salting into brine $\left(18-20^{\circ} \mathrm{Be} 10-12^{\circ} \mathrm{C}\right), 24-48 \mathrm{~h}$ \\
\hline $\begin{array}{l}\text { Ripening } \\
\text { Storage }\end{array}$ & $\begin{array}{l}\text { Ripening on } 12{ }^{\circ} \mathrm{C}-85 \% \mathrm{R} \text {, min. } 2 \text { months, the first days it is turned every } \\
\text { day, and in the later period once a week. Upon completion of the maturation, } \\
\text { next steps are washing, drying, coating, drying, labeling and packaging. } \\
\text { Storage in a refrigerator at } 4-8^{\circ} \mathrm{C} \text {, up to } 1 \text { year. }\end{array}$ \\
\hline
\end{tabular}


120 days and storage 7 months) were tested for protein content by standard ISO/TS 17837:2008 method, total nitrogen was determined according to Kjeldahl standard method, soluble nitrogen by Kjeldahl - Van Slyke standard method while the coefficient of maturity was measured by Kjeldahl/ Kjeldahl - Van Slyke standard method (AOAC 2001.14). The tests were done at the Department of Dairy Science, Belgrade, Serbia.

In all samples, the content of the amino acid (AA) was determined after acid hydrolysis using an HPLC method with diode array detector (DAD) (Henderson et al., 2000), while the determination of the free fatty acid (FA) in the cheese was done after methylation with borontrifluoride in methanol, using Shimadzu's gas chromatograph with flame ionization detector (FID) on InterCap WAX (length $30 \mathrm{~m}$, inner diameter $0.25 \mathrm{~mm}$, film thickness $0.25 \mu \mathrm{m}$ ) column (AOAC 996.06). Based on the obtained analytical results, the content of the analyzed components in the cheese samples was compared, considering the ripening time. The calculation of the dry matter distribution from milk into cheese and whey was carried out using Van Slyke and Price (1952) formula (taken from, Savić (2015)) and the formula for determining the amount of whey (in \%) was applied, (Popović-Vranješ and Vujičić, 1997). The results were statistically analyzed in Microsoft Office Excel 10 and presented as mean, range and coefficient of variation. At a same time, the obtained results of milk, cheese and whey were analysed using Statistica 9.0 and significant statistical differences were determined using t-test. The significance level was set at $\mathrm{p}<0.05$ and $\mathrm{p}<0.01$.

\section{Results and discussion}

\section{The quality of goat milk for cheese making}

Technology that is used in the production of hard goat cheese is different from that used in the preparation of cheese from cow's milk because of the differences between goat and cow milk (Popović-Vranješ, 2015). The production of hard cheese made from whole milk possesses a number of advantages compared to production of cheeses with reduced fat content. Fat contributes to taste and flavor of the cheese (Popović-Vranješ et al., 2013).
The composition of milk is constantly changing depending on the production requirements and payment criteria, and the milk of small ruminants is rarely standardized for cheese production (Pirisi et al., 2007). Generally, the production of goat cheese can be very problematic if we take into account the varying composition of goat milk during the year, particularly of fat and protein, and as a result cheeses made from the milk of different composition cannot keep the same features throughout the year (Božanić et al., 2002).

The results of chemical analysis of organic and conventional goat milk showed the statistically significant differences $(\mathrm{p}<0.05, \mathrm{p}<0.01)$ almost in relation to all ingredients, except in ash and sodium content (Table 2). The content of fat and protein amounted to 4.29 and $4.42 \%$, respectively, for organic, and 3.46 and $3.61 \%$, respectively, for conventional milk. While lactose content was higher in the conventional milk than organic one (4.18 vs. $3.53 \%$ ).

Goat milk which contains more dry matter, fat and protein coagulates faster and had firmer curd (Clark and Sherbon, 2000). Park and Haenlein (2010) stated that the level of fat in goat milk could vary from 2.4 to $7.8 \%$. The fat content is higher at the end of the season, and in different goat breeds. Fall milk contains 1\% more fat compared to summer milk (Gelaiset et al., 2000). In addition, the impact of the breed and lactation, milk composition always depends on the nutrition (Pirisi et al., 2007). Goats in organic farming must be fed $100 \%$ certified organic feedstuffs and minimum proportion of roughage in the ration should be $60 \%$ (Rahmann, 2009).

Mineral substances that are present in milk in small quantities are vital in cheese making (Jenness, 1980). Magnesium takes part in the micelles formation whereas the calcium and phosphates are included in the structure of the casein complex (Popović-Vranješ et al., 2009).

Organic milk compared to conventional, deposited significantly more calcium $(0.14$ vs. $0.10 \%$, $\mathrm{p}<0.05$ ), but with less of magnesium (171.2 vs. $226.3 \mathrm{mg} / \mathrm{kg}, \mathrm{p}<0.05, \mathrm{p}<0.01)$. At the same time, conventional milk was more abundant in $\mathrm{Zn}$ and $\mathrm{Fe}$ (4.316 and $2.087 \mathrm{mg} / \mathrm{kg}$ vs. 3.504 and $1.791 \mathrm{mg} / \mathrm{kg}$, $\mathrm{p}<0.05, \mathrm{p}<0.01)$, while the organic contained more $\mathrm{Cu}(0.454 \mathrm{mg} / \mathrm{kg}$ vs. $0.154 \mathrm{mg} / \mathrm{kg}, \mathrm{p}<0.05$, 
$\mathrm{p}<0.01)$. The high content of somatic cells can negatively affect the technological properties of milk and consequently affect the quality of the products. Kalantzopoulus et al. (2002) reported that high somatic cell count lead to a change in the milk composition, higher content of soluble protein and $\mathrm{Na}$, and had an impact on the ability of the udder to produce lactose. Raynal-Ljutovac et al. (2007) added the negative impact on the speed of coagulation and cheese production, while Chen et al. (2010) showed that the number of the somatic cell count of 1 to 1.5 million had no effect on the yield but sensory properties and texture of goat cheese were reduced.

\section{Production, quality and ripening}

The technology of organic hard goat cheese should be uniform and all technological parameters need to be controlled. If we observe the parameters in cheese production such as the distribution of dry matter from milk into cheese and whey, results showed a greater value for conventional in comparison to organic cheese (56.96 vs. $48.55 \%, \mathrm{p}<0.05$, $\mathrm{p}<0.01$ ) (Table 3).
The cheeses, which do not undergo a process of ripening, generally are poor in the dry matter, fat and protein and have a higher lactose content. Samples of 4 days old organic goat cheese have significantly higher level of moisture (61.09 vs. $59.68 \%, \mathrm{p}<0.05)$ while conventional contains more lactose and dry matter (7.72 vs $7.09 \%$, and 40.32 vs $38.91 \%, \mathrm{p}<0.05, \mathrm{p}<0.01)$. Barrucand and Raynal-Ljutovac (2011) reported similar levels of dry matter in the range of 37 to $46 \mathrm{~g} / 100 \mathrm{~g}$ in 4 days old goat cheeses. Regarding the fat and protein content on dry matter basis obtained results did not have significant differences (37.01 vs. $37.10 \%$ and 39.55 vs $38.44 \%, p<0.05, p<0.01)$. The calculated amount of whey obtained from conventional milk was $84.48 \%$ and for organic $79.22 \%(\mathrm{p}<0.05$, p<0.01). Popović-Vranješ and Vujičić (1997) suggested that the actual data relating to whey were always lower than the theoretical values due to losses incurred during production. Samples of hard organic goat cheese stored for a period of 7 months had an average composition of $28.80 \%$ protein, $30.17 \%$ fat and $0.62 \%$ lactose (Table 3 ).

Table 2. Average chemical composition of organic and conventional milk

\begin{tabular}{ccccc}
\hline Compound & Organic milk & SD & Conventional milk & SD \\
\hline DM $(\%)$ & $13.14^{\text {ac }}$ & 0.33 & $12.06^{\text {bd }}$ & 0.26 \\
\hline Moisture $(\%)$ & $86.86^{\text {ac }}$ & 0.33 & $87.94^{\text {bd }}$ & 0.27 \\
\hline Milk Fat $(\%)$ & $4.29^{\text {ac }}$ & 0.29 & $3.46^{\text {bd }}$ & 0.22 \\
\hline Proteins (\%) & $4.42^{\text {ac }}$ & 0.19 & $3.61^{\text {bd }}$ & 0.15 \\
\hline Lactose $(\%)$ & $3.53^{\text {ac }}$ & 0.17 & $4.18^{\text {bd }}$ & 0.16 \\
\hline Ash $(\%)$ & 0.90 & 0.49 & 0.81 & 0.28 \\
\hline Calcium $(\%)$ & $0.14^{\text {a }}$ & 0.04 & $0.10^{\text {b }}$ & 0.03 \\
\hline Phosphorus $(\%)$ & $0.14^{\text {ac }}$ & 0.01 & $0.11^{\text {bd }}$ & 0.02 \\
\hline Sodium $(\%)$ & 0.052 & 0.01 & 0.04 & 0.01 \\
\hline Potassium $(\%)$ & $0.085^{\text {ac }}$ & 0.05 & $0.09^{\text {bd }}$ & 0.05 \\
\hline Magnesium $(\mathrm{mg} / \mathrm{kg})$ & $171.2^{\text {ac }}$ & 5.53 & $226.3^{\text {bd }}$ & 5.80 \\
\hline Iron $(\mathrm{mg} / \mathrm{kg})$ & $1.791^{\text {ac }}$ & 0.09 & $2.087^{\text {bd }}$ & 0.05 \\
\hline Zinc $(\mathrm{mg} / \mathrm{kg})$ & $3.504^{\text {ac }}$ & 0.11 & $4.316^{\text {bd }}$ & 0.08 \\
\hline Copper $(\mathrm{mg} / \mathrm{kg})$ & $0.475^{\text {ac }}$ & 0.05 & $0.154^{\text {bd }}$ & 0.01 \\
\hline SCC $(* 1000 / \mathrm{mL})$ & $1502^{\text {ac }}$ & 58.46 & $1429^{\text {bd }}$ & 41.16 \\
\hline CFU $\left({ }^{\text {cd }} 1000 / \mathrm{mL}\right)$ & $1479^{\text {ac }}$ & 58.53 & $1367^{\text {bd }}$ & 37.58 \\
\hline
\end{tabular}

DM - Dry Matter, SCC - Somatic Cell Count; CFU - Colony Forming Units, SD-standard deviation

$a, b$ Means within a row marked with the different letter differ significantly $(p<0.05)$

$c, \mathrm{~d}$ Means within a row marked with the different letter differ significantly $(\mathrm{p}<0.01)$ 
Ripening of hard cheese takes several months, and with the creation of a natural crust it gets from delicate, fresh, gentle taste to milk and nuts taste (Popović-Vranješ et al., 2013). During cheese ripening, numerous physical-chemical changes are carried out which form a final cheese appearance and flavour. Biochemical changes during cheese ripening can be divided into two groups: primary (proteolysis, lipolysis and metabolism of residual lactose) and secondary (metabolism of amino and fatty acids). Primary are responsible for basic changes in texture while secondary form the final taste and smell of cheese. In cheese, more than 200 different volatile components can be found (Mikulec et al., 2010).
The unique taste of cheese is the result of a complex balance between volatile and non-volatile chemical compounds from milk fat, protein and carbohydrates that appeared during cheese ripening (Fox and Wallace, 1997).

Proteolysis in cheese directly affects the development of aroma and flavor of the cheese creating amino acids and peptides, whereby some can cause disadvantages in taste and changes in $\mathrm{pH}$ and texture (Fox et al., 1993). It is known that certain amino acids play an important role in flavors development, for example arginine affects bitterness, whereas proline, serine, and asparagine affect the sweetness (Izco and Torre, 2000). Changes in the content

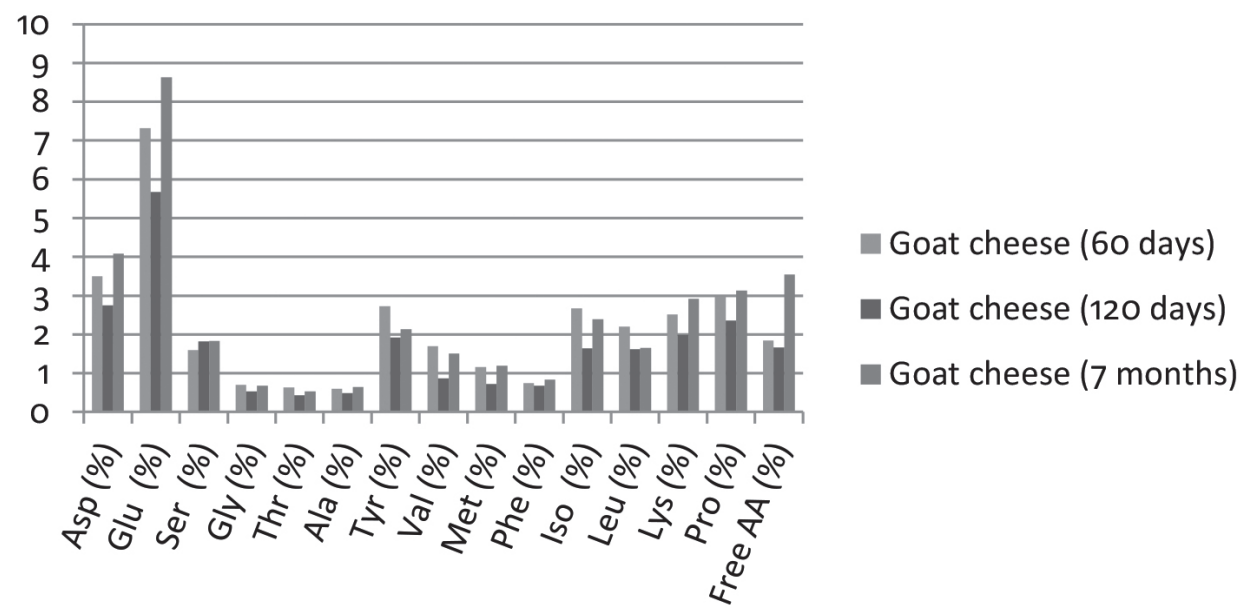

Figure 1. The changes in the content of amino acids during ripening and storage (\%)

Table 3. Average chemical composition of organic and conventional cheeses

\begin{tabular}{cccc}
\hline Parameter & $\begin{array}{c}\text { Organic cheese } \\
(4 \text { days })\end{array}$ & $\begin{array}{c}\text { Conventional cheese } \\
(4 \text { days })\end{array}$ & $\begin{array}{c}\text { Organic cheese } \\
(7 \text { months })\end{array}$ \\
\hline Moisture (\%) & $61.09^{\mathrm{a}}$ & $59.68^{\mathrm{b}}$ & 35.68 \\
\hline DM (\%) & $38.91^{\text {ac }}$ & $40.32^{\text {bd }}$ & 64.32 \\
\hline Proteins (\%) & 15.39 & 15.49 & 28.80 \\
\hline Fat (\%) & 14.40 & 14.96 & 30.17 \\
\hline Lactose (\%) & $7.09^{\mathrm{ac}}$ & $7.72^{\mathrm{bd}}$ & 4.62 \\
\hline Ash (\%) & 2.03 & 2.15 & 46.91 \\
\hline FDM (\%) & 37.01 & 37.10 & 44.78 \\
\hline PDM (\%) & 39.55 & 38.42 & \\
\hline $\begin{array}{c}\text { Substance distribution of } \\
\text { milk in cheese (\%) }\end{array}$ & $48.55^{\mathrm{ac}}$ & $56.96^{\mathrm{bd}}$ & \\
\hline Quantity of whey (\%) & $79.22^{\mathrm{ac}}$ & $84.48^{\mathrm{bd}}$ & \\
\hline
\end{tabular}

$\mathrm{a}, \mathrm{b}$ Means within a row marked with the different letter differ significantly $(\mathrm{p}<0.05)$

$\mathrm{c}, \mathrm{d}$ Means within a row marked with the different letter differ significantly $(\mathrm{p}<0.01)$

DM - dry matter, FDM - fat on dry matter basis, PDM - protein on dry matter basis,

substance distribution=dry matter of whey /dry matter of milk x 100 (VanSlyke and Publow, 1952, taken from Savić et al., 2015);

$\mathrm{Qw}(\%)=\mathrm{DMp}-\mathrm{DMm} / \mathrm{DMp}-\mathrm{DMw}$, Qw-quantity of whey, DMp-dry matter of the product, DMm-dry matter of milk,

DMw-dry matter of whey, (Popović-Vranješ and Vujičić, 1997). 
of amino acids (\%) during ripening and storage of organic hard goat cheeses are shown with Figure 1. Variations of quantitative relationships among free AA occurred as a result of a very complex enzymatic and microbial processes. Achieving maximum quantity of AA is in accordance with the highest degree of cheese age. The content of some AA and their total amount in the samples of cheese vary in all periods of ripening and storage that with regard to the content and accumulation of AA can be considered as unbalanced process. If we consider the content of essential AA in goat cheese, it can be said that the contents of threonine, tyrosine, valine, and isoleucine, decreased, whereas methionine, phenylalanine and lysine, showed a tendency to increase.

Also the content of some non-essential AA was different and the results confirmed the findings of extensive research regarding the accumulation of free $\mathrm{AA}$ in the ripening process of various cheeses. It was concluded that in relation to the initial phase of ripening, the amount of free AA had constant but unequal rise, with variations in very wide limits (Miletić, 1966 (a, b, c); Miletić, 1969).

In addition to taste, milk fat is an important factor of cheese softness and meltability. FA released in the process of cheese ripening and storage also showed variations in their quantity (Table 4).

Regarding saturated FA content in organic goat cheeses, myristic, palmitic and stearic acid were dominant while oleic acid was primary as unsaturated FA. Similar results were also established in study by Kravić et al., (2012) where $65 \%$ of total fatty acids in goat cheese were palmitic, capric, myristic and oleic acid. In cheese ripening, the content of myristic acid showed a decrease while stearic acid was increased. It was noted that over time the content of caprylic and capric fatty acids was reduced, while the highest variation in content was in case of linoleic and arachidonic acid (CV of 75.51 and $40.00 \%$, respectively). The most stable and with the slightest deviation were myristic and oleic acid (CV of 3.86 and $4.92 \%$, respectively).

As a true indicator of cheese ripening levels, ratio of soluble and total $\mathrm{N}$ (also called as coefficient of cheese ripening) can be used. Cheeses are different depending on the production technology and ripening conditions and they also differ from each other due to the extent of proteolysis and other changes that occur during the ripening period. Different content of soluble $\mathrm{N}$ (a widely-used proteolysis index) occurs because of the difference in moisture content, $\mathrm{pH}$ value, the ripening duration and curd drying temperature. In monitored samples, coefficients of ripening increased during the cheese ripening and storage time, from 12.87 to 24.56 (Table 5).

Content of soluble $\mathrm{N}$ and coefficient of ripening had a significant change in values and higher coefficients of variation (34.40 and $26.30 \%$ ) in relation to the content of nitrogen and protein (8.64 and $8.66 \%$, respectively). These results are in accordance with research by Slaveska et al. (1990).

Table 4. Changes in fatty acid content during ripening and storage (g/100 g)

\begin{tabular}{ccccc}
\hline Fatty acids & $\begin{array}{c}\text { Goat cheese } \\
\text { (60 days) }\end{array}$ & $\begin{array}{c}\text { Goat cheese } \\
(120 \text { days })\end{array}$ & $\begin{array}{c}\text { Goat cheese } \\
\text { (7 months })\end{array}$ & CV (\%) \\
\hline Butyric C4:0 & 1.60 & 1.73 & 1.39 & 8.92 \\
\hline Caprylic C8:0 & 2.74 & 2.78 & 1.87 & 17.07 \\
\hline Capric C10:0 & 9.10 & 8.29 & 5.81 & 18.11 \\
\hline Lauric C12:0 & 3.39 & 3.34 & 2.54 & 12.62 \\
\hline Myristic C14:0 & 8.26 & 7.55 & 8.13 & 3.86 \\
\hline Palmitic C16:0 & 23.71 & 23.18 & 28.08 & 8.76 \\
\hline Stearic C18:0 & 10.83 & 11.83 & 14.74 & 13.31 \\
\hline Oleic C18:1 & 26.37 & 29.13 & 26.22 & 4.92 \\
\hline Linoleic C 18:2 & 4.02 & 4.05 & 2.56 & 19.49 \\
\hline Linolenic C18:3 & 0.35 & 0.26 & 0.86 & 75.51 \\
\hline Arachidic C20:0 & 0.17 & 0.18 & 0.39 & 40.00 \\
\hline
\end{tabular}

CV - coefficient of variation 


\section{Goat whey quality}

Whey as a by-product of cheese production has a very variable composition. In the whey passes $50 \%$ of milk solids: mainly lactose and whey proteins as a whole, water-soluble minerals, and vitamins $\mathrm{B}$ complex, while vitamin $\mathrm{C}$ is already degraded during cheese production (Tratnik, 2003). In hard cheese production, intensity of curd cutting is significantly higher compared to soft and semi-hard cheeses and thus loss of dry matter and its transition in whey is higher as well. Also, during the reheating process which is typical for the production of hard cheeses, stirring and prolonged mechanical impact and the temperature effects results in a greater distribution of dry matter in whey (Srbinovska et al., 2001). Acidity is an important indicator of whey quality. Whey obtained after the coagulation of casein using enzymes is called sweet, while on the other hand, acid whey is the result of acid precipitation of casein. Different types of whey contain different ratios of minerals, protein and lactose, and may possess different functional properties (Pandya and Ghodke, 2007).

Analysis of whey in research carried out by Dozet et al. (1978) showed that the smallest fat and protein loss was found in milk containing high fat content, while in the production of cheese with low fat, the whey containing highest amount of protein was developed.

Based on the results of the whey composition variability comparison, it can be concluded that the largest deviations were found in case of acidity ( $\left.{ }^{\circ} \mathrm{SH}\right)$, protein and fat (CV of 40.78, 36.84 and $47.50 \%$ ), which indicated that the production technology of whey was not uniform and that the milk quality was different (Table 6).

The quantity of minerals in whey was highly variable due to different biochemical processes in cheese technology. Whey contains high amounts of soluble mineral nutrients, particularly the acid and casein type. Generally, the difference was associated with the amount of calcium and phosphorus, which were in form of a soluble calcium-phosphate (Tratnik, 2003). This depends on the whey $\mathrm{pH}$ and the point where the whey and curd are separated. This is the moment when the mineral composition of the cheese and the remaining lactose are largely determined. In case of cheeses such as protected designation of origin (PDO) and regional types of traditional cheeses, cheese production method effects the original milk differently and therefore mineral composition varies widely depending on the level of acid production and $\mathrm{pH}$ value of the whey (Lucey and Fox, 2014).

Considering macro elements, the highest deviations in the samples were found in case of $\mathrm{Ca}$ $(44.44 \%)$, while regarding trace elements, the highest variations were observed in case of $\mathrm{Zn}$ and $\mathrm{Cu}$ (29.09 and $44.60 \%$, respectively). The smallest differences among whey samples were related to the content of ash and K (5.26 and $4.76 \%$, respectively).

In all samples the presence of $\mathrm{Pb}$ was recorded and ranged from 0.234 to $2.340 \mu \mathrm{g} / \mathrm{kg}$, which was in compliance with European regulation (EC/1881/2006). On the other hand, Cd was not detected (Table 6). Comparing the samples of organic to conventional whey, the average dry matter content was similar and amounted to $6.38 \%$ (organic) and $6.40 \%$ (conventional). However, the differences existed regarding the total protein content which was significant higher in organic whey samples ( 1.43 and $0.52 \%, \mathrm{p}<0.05, \mathrm{p}<0.01)$. Lactose represents the largest proportion of whey and was more present in the conventional whey (3.56 vs. $4.51 \%, \mathrm{p}<0.05, \mathrm{p}<0.01)$. Moreover, conventional whey possessed more $\mathrm{Pb}(1.169$ vs $0.662 \mu \mathrm{g} / \mathrm{kg}$, respectively), but the difference was not significant $(p<0.05, p<0.01)$, and likewise the average content of other minerals.

Table 5. Amount of protein, total and soluble $\mathrm{N}$ and the coefficient of goat cheese maturity

\begin{tabular}{ccccc}
\hline Sample & Proteins (\%) & Total N (\%) & Soluble N (\%) & $\begin{array}{c}\text { Coefficient of } \\
\text { ripening }\end{array}$ \\
\hline Goat cheese (60 days) & 24.94 & 3.909 & 0.503 & 12.87 \\
\hline Goat cheese (120 days) & 23.52 & 3.687 & 0.643 & 17.44 \\
\hline Goat cheese (7 months) & 28.80 & 4.515 & 1.109 & 24.56 \\
\hline CV (\%) & 8.66 & 8.64 & 34.44 & 26.30 \\
\hline
\end{tabular}

CV (\%) coefficient of variation 


\section{Conclusion}

Technology development of organic goat hard cheese requires adjustment in production with organic production standards and established normative. The quality of organic goat milk is mostly derived from the production management and goat nutrition that should allow obtaining the raw material without the presence of antibiotics, pesticides and heavy metals. Investigated organic goat milk samples contained significantly more dry matter, fat and protein (13.14 vs. $12.06 \%, 4.29$ vs $3.46 \%$, and 4.42 vs. $3.61 \%, \mathrm{p}<0.05, \mathrm{p}<0.01)$ and from that point it is more suitable for the production of hard cheeses. At the same time, in comparison with conventional milk, hygienic quality of organic milk was significantly poorer $(\mathrm{p}<0.05, \mathrm{p}<0.01)$. Therefore, there is need to find a way how to improve the hygienic quality of the organic milk.

Organic goat cheese, aged 4 days contained significantly less dry matter (38.91 vs. $40.32 \%$, $\mathrm{p}<0.05, \mathrm{p}<0.01)$ while the fat on dry matter basis was almost equal (37.01 vs. $37.10 \%)$. The content of certain amino and fatty acids, as well as their total amount in the hard cheese samples, varies at all stages. Achieving the maximum amount of amino acids in analyzed cheeses was in accordance with the highest degree of ripening. Regarding the content of fatty acids, the largest variation was observed in case of linoleic and arachidonic acids (75.51 and $40.00 \%$, respectively), while myristic and oleic acids were quite constant in the process of cheese ripening and storage (CV of 3.86 and $4.92 \%$, respectively).

There is a possibility of producing hard goat cheeses of controlled and consistent quality, if there is market demand, through the process of introducing standardization of technological process and the ripening conditions. Investigation of the whey quality confirmed the assertion of their unequal and variable composition. Organic whey contained significantly more total protein, but regarding the content of dry matter there were no significant differences (6.38 and $6.40 \%$, respectively, $(\mathrm{p}<0.05, \mathrm{p}<0.01)$ ).

Table 6. Descriptive statistics of monitored variable

\begin{tabular}{|c|c|c|c|c|}
\hline Variables & $\begin{array}{c}\text { Range } \\
\text { (xmin-xmax) }\end{array}$ & Arithmetic mean & SD & $\mathrm{CV}(\%)$ \\
\hline $\mathrm{pH}$ value & $4.60-6.54$ & 5.81 & 0.68 & 11.70 \\
\hline $\begin{array}{l}\text { Titratable acidity } \\
\left({ }^{\circ} \mathrm{SH}\right)\end{array}$ & $5.0-16$ & 9.17 & 3.74 & 40.78 \\
\hline Dry matter $(\%)$ & $5.90-7.14$ & 6.40 & 0.46 & 7.18 \\
\hline Proteins (\%) & $0.78-2.04$ & 1.14 & 0.42 & 36.84 \\
\hline Fat $(\%)$ & $0.1-0.6$ & 0.4 & 0.19 & 47.50 \\
\hline Lactose (\%) & $3.18-5.20$ & 4.29 & 0.62 & 14.45 \\
\hline Ash (\%) & $0.54-0.62$ & 0.57 & 0.03 & 5.26 \\
\hline $\mathrm{Ca}(\%)$ & $0.02-0.06$ & 0.036 & 0.016 & 44.44 \\
\hline P (\%) & 0.04-0.06 & 0.046 & 0.007 & 15.22 \\
\hline $\mathrm{Na}(\%)$ & $0.04-0.053$ & 0.046 & 0.005 & 10.87 \\
\hline K (\%) & 0.079-0.088 & 0.084 & 0.004 & 4.76 \\
\hline $\mathrm{Mg}(\mathrm{mg} / \mathrm{kg})$ & $72.79-97.60$ & 86.38 & 7.878 & 9.12 \\
\hline $\mathrm{Fe}(\mathrm{mg} / \mathrm{kg})$ & $1.069-1.717$ & 1.323 & 0.217 & 16.40 \\
\hline $\mathrm{Zn}(\mathrm{mg} / \mathrm{kg})$ & $0.40-0.822$ & 0.598 & 0.174 & 29.09 \\
\hline $\mathrm{Cu}(\mathrm{mg} / \mathrm{kg})$ & $0-0.427$ & 0.213 & 0.095 & 44.60 \\
\hline $\mathrm{Pb}(\mu \mathrm{g} / \mathrm{kg})$ & $0.234-2.34$ & 1.085 & 0.645 & 59.46 \\
\hline $\mathrm{Cd}(\mu \mathrm{g} / \mathrm{kg})$ & - & - & - & - \\
\hline
\end{tabular}

SD - standard deviation, CV - coefficient of variation, minimal (min) and maximal (max) values of variables 


\section{Proizvodnja tvrdog kozjeg sira i sirutke od organskog kozjeg mlijeka}

\section{Sažetak}

Proizvodnja tvrdih kozjih sireva i sirutke iz organskog kozjeg mlijeka vrlo je kompleksna i mora biti usklađena s metodama i propisima organske proizvodnje. Organski tvrdi kozji sirevi deklariraju se kao proizvodi visoke kvalitete, s većom ili dodanom vrijednošću, a da bi se to postiglo svi tehnološki parametri proizvodnje moraju biti kontrolirani i prilagođeni tipu željenog sira. U ovom ispitivanju izvršene su kemijske analize sastava organskog i konvencionalnog kozjeg mlijeka, sira i sirutke. Profil masnih kiselina bio je određen plinskom kromatografijom s FID detektorom, dok je za identifikaciju aminokiselina korištena HPLC metoda $\mathrm{s}$ fluorescentnim detektorom. Podatci dobiveni $\mathrm{u}$ istraživanju bili su analizirani primjenom Statistica 9.0 paketa a signifikantne razlike određene su upotrebom t-testa. Na temelju dobivenih rezultata organsko mlijeko bilo je značajno bogatije svim sastojcima, osim u sadržaju pepela i natrija $(\mathrm{p}<0,05$, $\mathrm{p}<0,01)$. Suprotno, sirevi (stari 4 dana) nisu pokazali statistički značajne razlike, s izuzetkom udjela suhe tvari i laktoze $(\mathrm{p}<0,05, \mathrm{p}<0,01)$. Tijekom zrenja organskih sireva udjel treonina, tirozina, valina i izoleucina se smanjivao dok su metionin, fenilalanin i lizin pokazivali tendenciju porasta. U pogledu sadržaja zasićenih masnih kiselina u siru više su bile zastupljene miristinska, palmitinska i stearinska, dok je od nezasićenih masnih kiselina dominirala oleinska. Uzorci organske sirutke sadržavali su više proteina $(1,43 \%$ prema $0,52 \%, p<0,05, p<0,01)$. Primjena organskih standarda proizvodnje i kontrola svih tehnoloških parametara u proizvodnji organskih tvrdih kozjih sireva i sirutke rezultirali su dobivanjem visoko kvalitetnih proizvoda.

Ključne riječi: tehnologija, organski tvrdi kozji sir, sirutka

\section{References}

1. Barrucand, P., Raynal-Ljutovac, K. (2012): Relationship between technological steps and behavior of French goat cheeses for culinary applications. Special Issue of the International Dairy Federation 1201. IDF International Symposium on Sheep, Goat and other non-Cow Milk. 16-18 May. Athens, Greece, 54-65.

2. Bovera, F., Piccolo, G., Calabro, S., Cutrignelli, M.I., Zicarelli, F., Infascelli, F. (2007): Influence of organic systems on milk yield and quality of Cilentana goats. Options Mediterraneens 74, 83-87.

3. Božanić, R., Tratnik, Lj., Drgalić, I. (2002): Kozje mlijeko: karakteristike i mogućnosti. Mljekarstvo 52 (3), 207-237.

4. Clark, S., Sherbon, J.W. (2000): Alpha sl-casein, milk composition and coagulation properties of goat milk. Small Ruminant Research 38, 123-134. https://doi.org/10.1016/S0921-4488(00)00154-1

5. Chen, S.X., Wang, J.Z., Van Kessel, J.S., Ren, F.Z., Zeng, S.S. (2010): Effect on somatic cell count in goat milk on yield, sensory quality, and fatty acid profile of semisoft cheese. Journal of Dairy Science 93 (4), 1345-1354. https://doi.org/10.3168/jds.2009-2366

6. Dozet, N., Stanišić, M., Bijeljac, S (1978): Standardizacija mlijeka u proizvodnji sira. Mljekarstvo 28 (7), 156-162.

7. Dozet, N., Stanišić, M., Bijeljac, S. (1979): Utjecaj kravljeg i ovčijeg mlijeka na kvalitet sira. Mljekarstvo 29 (4), 87-95.

8. EC (2006): Commisssion Regulation No1881/2006. Setting maximum levels of certain contaminanats in foodstuffs. Official Journal of the European Union. L/364.

9. EC (2008): Commission Regulation (EC) No 889/2008 of 5 September 2008 laying down detailed rules for the implementation of Council Regulation (EC) No 834/2007 on organic production and labelling of organic products with regard to organic production, labelling and co, 16(834).

10. EDA (European Dairy Assocition) Economic Report 2016/17. www.euromilk.org

11. EEC (1993): Commission Regulation (EEC) No 207/93 of 29 January 1993 defining the content of Annex VI to Regulation (EEC) No 2092/91 on organic production of agricultural products and indications referring thereto on agricultural products and foodstuffs and laying.

12. Gelais, D.S., Ould B.A., Tureot, S. (2000): Composition of goat's milk processing suitability. Journal of agricultural science, 5-10.

13. Fox, P.F., Law, J., Mcsweeney, P.L.H., Wallace, J. (1993): Biochemistry of cheese ripening in cheese: chemistry, physics and microbiology. Ed. By Fox, P.F., Chapman \& Hall, London And New York. Volume 1. General aspects. Second edition. Chapter 10, 389-438.

14. Fox, P.F., Wallace, J.M. (1997): Formation of flavor compounds in cheese. $A d$ vances in Applied Microbiology 45, 17-85. https://doi.org/10.1016/S0065-2164(08)70261-2

15. Haenlein, G.F.W. (2004): Goat milk in human nutrition. Small Ruminant Research 51, 155-163. https://doi.org/10.1016/j.smallrumres.2003.08.010

16. Henderson, W.J., Robert, D., Ricker, D.R., Bidlingmeyer, A.B., Woodward, C. (2000): Rapid, accurate, sensitive and reproducible HPLC analysis of amino acids amino acid analysis using Zorbax Eclipse-AAA columns and the Agilent 1100 HPLC. Agilent Technologies. PN 59801193E. 
17. Izco, J.M., Torre, P. (2000): Characterisation of volatile flavour compounds in Roncal cheese extracted by the "purge and trap" method and analysed by GC-MS. Food Chemistry 70 (3), 409-417. https://doi.org/10.1016/S0308-8146(00)00100-X

18. Jennes, R. (1980): Composition and characteristics of goat milk. Review 1968-1979. Journal of Dairy Science 63, 1605-1630. https://doi.org/10.3168/jds.s0022-0302(80)83125-0

19. Kravić, S., Brezo, T., Karišik-Djurović, A., Suturović, Z., Milanović, S., Švarc-Gajić, J., Stojanović, Z. (2012): Masnokiselinski sastav kozjih sireva. Prehrambena industrija - Mleko i mlečni proizvodi 23 (1), 49-52.

20. Kalantzopoulus, G., Dubeuf, J.P., Vallerand, F., Pirisi, A., Casalta, E., Lauret, A., Trujillo, T. (2002): Characteristics of the sheep and goat milks: Quality and Hygienic stakes for the sheep and goat dairy sectors. IDF SC on Microbiological hygiene, Meeting 28 September 2002, Agenda item 4.8.

21. Kirk, S.R., Sawyer, R. (1991): Pearson's Composition Analysis of Food. AWL, Harlow, England, UK.

22. Krolczyk, B.J., Dawidziuk, T., Janiszewska-Turak, E., Solowiej, B. (2016): Use of whey and whey preparations in the food industry - a review. Polish Journal of Food and Nutrition Sciences 66 (3). https://doi.org/10.1515/pjfns-2015-0052

23. Lucey, J.A., Fox, P.F. (2014): Importance of calcium and phosphate in cheese manufacture: a review. Journal of Dairy Science 76 (6), 1714-1724. https://doi.org/10.3168/jds.S0022-0302(93)77504-9

24. Malissiova, E., Tzora, A., Katsioulis, A., Hatzinikou, M., Tsakalof, A., Arvanitoyannis, S. I., Govaris, A., Hadjichristodoulou, C. (2015): Relationship between production conditions and milk gross composition in ewe's and goat's organic and conventional farms in central Greece. Dairy Science \& Technology 95 (4), 437-450. https://doi.org/10.1007/s13594-015-0224-7

25. Mikulec N., Habuš, I., Antunac, N.,Vitale Lj., Havranek J. (2010): Uticaj peptida i aminokiselina na formiranje arome sira. Mljekarstvo 60 (4), 219-227.

26. Miletić, S. (1966a): Slobodne aminokiseline u procesu zrenja sira trapista. Poljoprivredna znanstvena smotra 6, Zagreb.

27. Miletić, S. (1966b): Akumulacija slobodnih aminokiselina u toku zrenja našeg sira "gruyere". Poljoprivredna znanstvena smotra 11, Zagreb.

28. Miletić, S. (1966c): Sadržaj slobodnih aminokiselina sira ribanca. Poljoprivredna znanstvena smotra 12, Zagreb.

29. Miletić, S. (1969): Akumulacija slobodnih aminokiselina u procesu zrenja našeg sira edemca. Poljoprivredna znanstvena smotra 16 , Zagreb.

30. Morand-Fehr, P., Boutonnet, J.P., Devendra, C., Dubeuf, J.P., Haenlein, G.F.W., Holst, P., Mowlem, L., Capote, J. (2004): Strategy for goat farming in the 21 st century. Small Ruminant Research 51, 175-183. https://doi.org/10.1016/j.smallrumres.2003.08.013

31. OMSCo (2015): Organic milk market report. www. omsco.co.uk

32. Pajor, F., Kerti, A., Penkza, K., Kuchtik, J., Harkanyine Szekely, Zs., Beres, A., Czinkota, I., Szentes, Sz., Poti, P. (2014): Improving nutritional quality of the goat milk by grazing. Applied Ecology and Environmental Research 12 (1), 301-307. https://doi.org/10.15666/aeer/1201_301307
33. Pandya, A.J., Ghodke, K.M. (2007): Goat and sheep milk products other than cheeses and yoghurt. Small Ruminanat Research 68, 193-206. https://doi.org/10.1016/j.smallrumres.2006.09.007

34. Park, Y.W., Haenlein, G.F.W. (2006): Handbook of milk of non-bovine Mammals. Blackwell Publishing Professional. USA. www.blackwellprofessional.com https://doi.org/10.1002/9780470999738

35. Park, Y.W., Haenlein, G.F.W. (2010): Milk production. In: Goat Science and Production. Solaiman, S.G. (Editor). Wiley-Blackwell. Ames, Iowa, 275-292.

36. Pirisi, A., Lauret, A., Dubeuf, J.P. (2007): Basic and incentive payments for goat and sheep milk in relation to quality. Small Ruminanat Research 68, 167-178. https://doi.org/10.1016/j.smallrumres.2006.09.009

37. Popović-Vranješ, A., Vujičić, I.F. (1997): Tehnologija sirutke, monografija. Poljoprivredni fakultet, Novi Sad.

38. Popović-Vranješ, A., Kranjinović, M., Pejanović, R., (2009): Utjecaj mlijeka, aditiva i tehnologije na kemijski sastav i senzorna svojstva sira trapista. Mljekarstvo 59 (1) 70-77.

39. Popović-Vranješ, A., Kasalica, A., Pejanović, R., Jevtić, M., Cvetanović, D., Grubješić, G. (2013): Peculiarities of added value hard cheese production, $23^{\text {rd }}$ International symposium "New Technologies in Contemporary Animal Production”, Novi Sad (Serbia), 19.-21. Jun, 2013.

40. Popović-Vranješ, A. (2015): Specijalno sirarstvo. Univerzitet u Novom Sadu. Poljoprivredni fakultet, Departman za stočarstvo, Novi Sad.

41. Raynal-Ljutovac, K., Pirisi, A., De Cremoux, R., Gonzalo, C. (2007): Somatic cells of goat and sheep milk: analytical, sanitary, productive and technological aspects. Small Ruminant Research 68, 126-144. https://doi.org/10.1016/j.smallrumres.2006.09.012

42. Rahmann, G. (2009): Performance of organic goat milk production in grazing systems in Northern Germany. Landbauforschung - vTI Agriculture and Forestry Research 1 (59), 4l-46.

43. Sabadoš, D. (1996): Quality control of milk and dairy products. Hrvatsko mljekarsko društvo, Zagreb.

44. Savić, Ž., Radović, B., Ilić, Z. (2015): Randman proizvodnje i distribucija sastojaka u mleka u siru pri autohtonoj proizvodnji sjeničkog sira. Agroznanje 16 (4), 531-538.

45. Slaveska, Lj., Kršev, Lj., Slaveska, R., Petkovska B. (1990): Dinamika sadržaja ukupnog i topivog dušika, odnosno koeficijenta zrelosti bijenog sira u toku zrenja i čuvanja u salamuri. Mljekarstvo 40 (5) 129-133.

46. Srbinovska, S., Čizbanovski, T., Džabirski, Andonov, S., Palasevski, B. (2001): Dynamics of salt diffusion and yield of three types of goat's milk cheese. Mljekarstvo 51 (1), 15-26.

47. Tratnik, Lj. (2003): Uloga sirutke u proizvodnji funkcionalne mliječne hrane. Mljekarstvo 53 (4), 325-352.

48. Tudisco, R., Cutrignelli I. M., Calabro, S., Piccolo, G., Bovera, F., Guglielmelli, A., Moniello, G., Infascelli, F. (2010): Influence of organic systems on milk fatty acid profile and CLA in goats. Small Ruminanat Research 88, 151-155. https://doi.org/10.1016/j.smallrumres.2009.12.023

49. Wolf, K. (2014): Differences in bovine and caprine cheese production. Kansas City Convention Centre. ADSA-SAD Undergraduate Presentations-Dairy Foods. Kanasas City, Mo July 20-24, 2014. 